University of Nebraska - Lincoln

DigitalCommons@University of Nebraska - Lincoln

Publications from USDA-ARS / UNL Faculty

U.S. Department of Agriculture: Agricultural

Research Service, Lincoln, Nebraska

2012

\title{
Potential causes and consequences of decreased body size in field populations of Coccinella novemnotata
}

\author{
John Losey \\ Cornell University, jel27@cornell.edu \\ Jordan Perlman \\ Cornell University, jep66@cornell.edu \\ James Kopco \\ Cornell University, jk729@cornell.edu \\ Samuel Ramsey \\ Cornell University, sdr26@cornell.edu \\ Louis Hesler \\ USDA-ARS North Central Agricultural Research Laboratory, louis.hesler@ars.usda.gov \\ See next page for additional authors
}

Follow this and additional works at: https://digitalcommons.unl.edu/usdaarsfacpub

Part of the Agricultural Science Commons

Losey, John; Perlman, Jordan; Kopco, James; Ramsey, Samuel; Hesler, Louis; Evans, Edward; Allee, Leslie; and Smyth, Rebecca, "Potential causes and consequences of decreased body size in field populations of Coccinella novemnotata" (2012). Publications from USDA-ARS / UNL Faculty. 859.

https://digitalcommons.unl.edu/usdaarsfacpub/859

This Article is brought to you for free and open access by the U.S. Department of Agriculture: Agricultural Research Service, Lincoln, Nebraska at DigitalCommons@University of Nebraska - Lincoln. It has been accepted for inclusion in Publications from USDA-ARS / UNL Faculty by an authorized administrator of DigitalCommons@University of Nebraska - Lincoln. 


\section{Authors}

John Losey, Jordan Perlman, James Kopco, Samuel Ramsey, Louis Hesler, Edward Evans, Leslie Allee, and Rebecca Smyth 


\title{
Potential causes and consequences of decreased body size in field populations of Coccinella novemnotata
}

\author{
John Losey ${ }^{\mathrm{a}, *}$, Jordan Perlman ${ }^{\mathrm{a}}$, James Kopco ${ }^{\mathrm{a}}$, Samuel Ramsey ${ }^{\mathrm{a}}$, Louis Hesler ${ }^{\mathrm{b}}$, Edward Evans ${ }^{\mathrm{c}}$, \\ Leslie Allee $^{\mathrm{a}}$, Rebecca Smyth ${ }^{\mathrm{a}}$ \\ ${ }^{a}$ Department of Entomology, Comstock Hall, Cornell University, Ithaca, NY 14853, USA \\ ${ }^{\mathrm{b}}$ USDA-ARS North Central Agricultural Research Laboratory, 2923 Medary Avenue, Brookings, SD 57006, USA \\ ${ }^{\mathrm{c}}$ Utah State University, Department of Biology, UMC 5305, Logan, UT 84322, USA
}

\section{H I G H L I G H T S}

Recent Coccinella novemnotata were significantly smaller than historical specimens.

- Offspring fed ad libitum prey were not smaller than historical specimens.

- Varying prey availability alone was sufficient to reproduce observed size variation.

\section{A R T I C L E I N F O}

\section{Article history:}

Received 11 October 2011

Accepted 21 December 2011

Available online 29 December 2011

\section{Keywords:}

Invasive species

Scramble competition

Rare species

Predator

Coccinellid
G R A P H I C A L A B S T R A C T

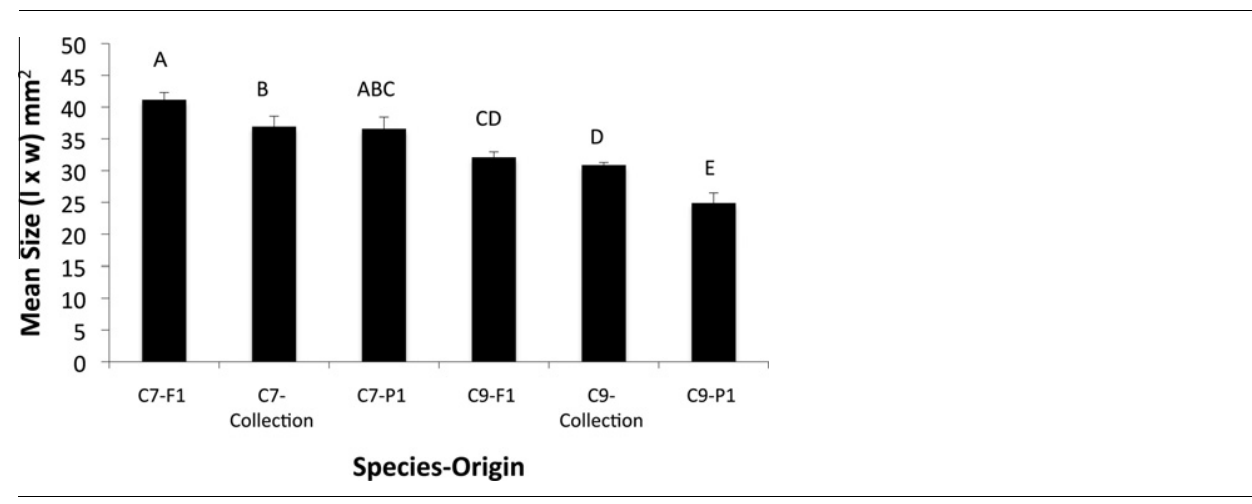




\section{Introduction}

\subsection{Background}

Body size is correlated with many determinants of fitness (Blueweiss et al., 1978) including fecundity (Honek, 1993), survival (Savage et al., 2004), and the ability to secure resources such as prey (Menge, 1972) and mates (Howard et al., 1997). The study of why some species' average body sizes have changed over time while others have not has the potential to shed light on the impact of several broad-scale long-term environmental changes including climate change (Roy, 2008; Smith et al., 1995) and interactions with invasive species (Brown and Maurer, 1986; Phillips and Shine, 2004). If the focal species is a biological control agent then changes in body size may impact its ability to suppress pest populations. If a species that was introduced as a biological control agent is partly or fully responsible for the size change in the focal species then there are potentially serious nontarget issues that need to be addressed (Phillips and Shine, 2004).

Once it has been determined that the mean size of individuals of a focal species has changed significantly over time beyond nontime dependent levels of variation (e.g. clines), discovering the reason for the change can offer insights into how the organism interacts with its changing environment. Comparing size changes of multiple species from similar habitats can allow additional insights by discerning why some species are impacted while others are not. Several factors could account for a shift in mean size over time, including (1) a change in resource availability, (2) infection with a pathogen, (3) size-dependent mortality, or (4) a genetic shift to a different size. Ecological factors (1-3 above) can be separated from genetic changes by manipulating ecological conditions while controlling for genetic factors (Naguib and Gil, 2005).

While the causes and consequences of body size have been studied for almost all animal taxa, one group where clear effects have been demonstrated is the insects. Both underlying genetic variation (Dingle, 1984) and environmental conditions during development (Gullan and Cranston, 1994; Hodek and Honek, 1996) have been shown to impact adult size in insects. Within this class of animals, prey availability during development, specifically, has been shown to impact body size in coccinellids (Blackman, 1965; Honek, 1993; Obrycki and Orr, 1990; Orr and Obrycki, 1990; Phoofolo et al., 2008).

One species of coccinellid of great current interest is the ninespotted lady beetle Coccinella novemnotata Herbst. Up until the mid-1980s, this was the most prevalent species of lady beetle in the northeastern United States (Harmon et al., 2007). It served as an important biological control agent, moderating aphid populations in gardens and crops throughout the northeast. Yet, in 1993, an extensive USDA APHIS coccinellid survey found no evidence of the nine-spotted lady beetle in eleven Northeastern states. This cooperative study focused on 100 counties and was based on comprehensive fieldwork and data from personal collections. The most recent published records report that the ninespotted lady beetle was last collected on the eastern seaboard in 1992 (Harmon et al., 2007). For more than a decade, entomologists have pondered the disappearance of $C$. novemnotata, but speculated that it might continue to persist in low densities across the United States (Wheeler and Hoebeke, 1995). The initial decline in the $C$. novemnotata population in eastern North America appears to align with the introduction of the European, seven-spotted lady beetle (Coccinella septempunctata) (Wheeler and Hoebeke, 1995). The seven-spotted lady beetle has since proven to be a powerful alternative to chemical management of agrarian pests (Hoffmann and Frodsham, 1993), but it may have had a negative impact on native species of coccinellids (Alyokhin and Sewell, 2004; Elliot et al., 1996; Ellis et al., 1999; Simberloff and Stiling, 1996; Snyder et al., 2004; Staines et al., 1990; Wheeler and Hoebeke, 1995). Several alternative hypotheses have been proposed to explain the decline of $C$. novemnotata (e.g. land use change, climate change) that do not cite the introduction of $C$. septempunctata as the cause. These theories are logical in principle, but do not appear to align directly with the known time period for $C$. novemnotata disappearance (see Harmon et al., 2007).

The primary challenge in reaching a definitive conclusion regarding the effects of $C$. septempunctata on $C$. novemnotata is that very little data were systematically collected as $C$. septempunctata expanded and $C$. novemnotata contracted its range (Gordon, 1985; but see Evans, 2000). The Lost Ladybug Project (www.lostladybug.org), founded in 2000, utilizes citizen science to track the distribution and abundance of lady beetles across North America. It is the first initiative that attempts to fill the void left by the historical lack of methodological surveys. Since its inception, the Lost Ladybug Project has collected over 11,000 lady beetle specimens, and its investigators have established sustainable colonies of rare coccinellids. In 2006, after a 14-year lapse of sighting, a nine-spotted lady beetle ( $C$. novemnotata) was discovered in Washington, DC (Losey et al., 2007). A grant from the National Science Foundation has allowed the Lost Ladybug Project to broaden its outreach and, since 2008, the initiative has logged images of over 40 individual $C$. novemnotata and collected over 30 live specimens, exclusively from the western states. Cornell University is home to one of just two colonies of $C$. novemnotata in the United States. Initial observations of the live $C$. novemnotata that were collected by the Lost Ladybug Project in 2008-2009 suggested that the individuals appeared to be notably smaller than historical specimens while the mean size of individuals of its congeneric potential competitor, $C$. septempunctata, did not appear changed.

\subsection{Objectives}

We initiated this study by assessing if the average size of $C$. novemnotata adults was indeed declining. To accomplish this we determined if the size of current $C$. novemnotata populations fell within the historical size range of individuals before the species declined. To investigate the causes and consequences of size change in $C$. novemnotata individuals in field populations we then compared the sizes of recently collected $C$. novemnotata and $C$. septempunctata specimens to the offspring of field-collected adults which have been reared in the laboratory with access to ad libitum prey. Finally, to ascertain if prey limitation could be the sole cause of size decline we set out to determine if the range in size of recently collected adult $C$. novemnotata could be duplicated by varying access to prey.

\section{Methods}

\subsection{Rearing lady beetles}

Adult $C$. novemnotata were placed in a separate colony and allowed to mate freely. All beetles, regardless of developmental phase, were placed on a $16 \mathrm{~h}$ light cycle, and lab temperature was set at a consistent $21^{\circ} \mathrm{C}$. Eggs were collected from each colony and observed for signs of fertilization. Coccinellid eggs are normally bright yellow to orange in color. Viable eggs retain the coloration, while nonviable eggs shrivel and turn dark brown or black within 2-3 days of oviposition. Clusters of viable eggs were placed in cylindrical, plastic containers, each with a volume of $44 \mathrm{ml}$. Each container stored a single egg cluster. Each cluster yielded approximately 3-7 individual first-instar larvae after approximately four 
Table 1

The number of beetles measured from each origin.

\begin{tabular}{|c|c|c|c|c|c|}
\hline Origin & Species & Sample size & Mean area $(l \times w) \pm S E M$ & Location & Date collected \\
\hline Field collected (P1) & C. novemnotata & 8 & $24.82 \pm 2.29$ & OR & June 10-11, 2009 \\
\hline Field collected (P1) & C. novemnotata & 13 & $24.95 \pm 1.79$ & $\mathrm{SD} / \mathrm{NE}$ & June 18,2008 ; early July 2009 \\
\hline Field collected (P1) & C. novemnotata & 6 & $29.66 \pm 2.64$ & UT & Spring 2011 \\
\hline Field collected (P1) & C. novemnotata & 11 & $24.36 \pm 1.95$ & $\mathrm{CO}$ & May 27, 2011 \\
\hline Raised in culture (F1) & C. novemnotata & 41 & $37.66 \pm 1.62$ & NY (Cornell) & - \\
\hline Raised in culture (F1) & C. novemnotata & 33 & $25.17 \pm 1.13$ & SD (USDA) & - \\
\hline Collection & C. novemnotata & 180 & $30.71 \pm 0.48$ & NY (CUIC) & - \\
\hline Collection & C. novemnotata & 74 & $28.09 \pm 0.75$ & DC (Smith.) & - \\
\hline Collection & C. novemnotata & 50 & $35.56 \pm 0.91$ & UT & - \\
\hline Field collected (P1) & C. septempunctata & 16 & $36.59 \pm 1.62$ & OR & June 10-11, 2009 \\
\hline Raised in culture (F1) & C. septempunctata & 41 & $41.15 \pm 1.01$ & NY (Cornell) & - \\
\hline Collection & C. septempunctata & 20 & $36.77 \pm 0.80$ & NY (CUIC) & - \\
\hline
\end{tabular}

days. To provide prey, the lab maintains a mixed colony of Acyrthosiphon pisum (pea aphid) and Myzus persicae (green peach aphid). The aphids were reared on Vicia faba (fava bean), and the aphid colony was kept in a moist growth chamber, at a constant temperature of $23^{\circ} \mathrm{C}$. Feeding practices were kept consistent until larvae reached the third instar. Developmental instar was confirmed by counting the number of moults. All individuals in a container were determined to have moulted when the number of exuviae equaled the number of larvae. No larvae moulted twice before all individuals had completed a single instar. At the third instar, larvae were separated into individual containers, each with a piece of paper towel to be used as an anchor for later pupation. After hatching, it took each larva approximately 4-5 days to reach third instar. Each third instar larva was fed roughly 15 aphids daily. Individuals were closely observed for fungal infection (Microsporidia) until pupation. From the onset of the third instar, it took each larva approximately 7 days to pupate. Each individual spends about 1 day in a pre-pupal stage where the larva ceases to eat and appears sluggish. It took approximately 4 days to emerge as adults. All newly emerged adult coccinellids were not fed for $24 \mathrm{~h}$ as their elytra hardened. Once they resumed normal feeding habits (roughly 15 aphids daily), adult coccinellids were returned to their respective colonies to mate.

\subsection{Measuring lady beetles}

Lady beetles for measurement were acquired from (1) field collections $\{$ P1 $\}$ from eastern Oregon, northwestern Nebraska, and southwestern South Dakota, (2) the following insect collections: The Cornell University Insect Collection, The Smithsonian Institution, The Utah State University Insect Collection and, (3) laboratory colonies \{F1 and beyond $\}$ maintained at Cornell University and at the USDA-ARS Laboratory in Brookings, South Dakota. The number of beetles measured from each origin is listed in Table 1 . All of the individuals used for this study were dead. Coccinellids from collections were pinned specimens. All other specimens were stored in $70 \%$ isopropyl alcohol.

Measurements were taken using calipers or a microscope micrometer, both with accuracy to $0.01 \mathrm{~mm}$. Individuals taken from storage in alcohol were allowed to dry before dimensions were taken. To enhance visual contrast, coccinellids were placed on white filter paper. The length measurement was taken from the tip of the head to the tip of the abdomen. The width measurement was taken across the widest portion of the insect. For some specimens, height was also measured to allow calculation of volume as, potentially, the most accurate measure of overall size. In order to acquire height measurements, each individual was placed on its side, and the dimension was again calculated across the widest portion of the abdomen. The volume was determined using a formula for hemi-ellipsoid volume: (4/3) $\pi[$ (Length) $/ 2 \times$ (Width)/
$2 \times$ (Height)]. Regression analysis confirmed that area $(1 \times \mathrm{w})$ is an excellent predictor of volume $\left(R^{2}=0.998\right)$. Since coccinellids are generally ovate, area could be expressed as the area of an ellipse $(1 \times \mathrm{w} \times \pi)$ but since the amount of curvature at both anterior and posterior varies among species and individuals we chose to analyze and present all data as simple rectangular area $(1 \times \mathrm{w})$. Hereafter, we will use "size" to denote rectangular area $(1 \times \mathrm{w})$.

\subsection{Feeding study}

In order to determine the effects of prey availability on ultimate adult size, 104 first-instar $C$. novemnotata larvae were selected from the laboratory colony, and divided into five subgroups to be reared at varying prey levels. Larvae were placed in individual containers within $24 \mathrm{~h}$ of hatching with a piece of paper towel as an anchor for eventual pupation. Containers were labeled to represent the appropriate experimental group. Larvae were fed a random mix of pea and green peach aphids at densities of $1,3,12,21$, or 30 aphids per 24-h period. All uneaten aphids were removed before new aphids were added, so uneaten aphids did not accumulate in the containers. Twenty replications were set up for each treatment except for prey densities of 1 and 12 for which 22 replications were initiated. The feeding regimens were selected based on preliminary studies to produce variation in adult sizes, while preserving a high level of survivorship at the higher levels. Aphids were replaced every 24-h regardless of the number consumed in the previous period. Developmental stage and all fatalities were noted daily for each individual until each of the original 104 individual beetles died. Upon emergence, adults were fed while their elytra hardened. Within 5 days of emergence, measurements of adult length, width, and height were taken as noted above.

\subsection{Statistical analysis}

Since sex ratio data was not available for all data sets and since the sex ratio was approximately 50:50 for all groups of adult beetles, sexes are lumped for calculating mean beetle sizes. The relationships between longitude, latitude, year, Julian date, elevation and all their interactions and the size of $C$. novemnotata from museum collections were analyzed individually with a regression analysis on JMP using backward selection starting with the saturated model. The mean size of $C$. novemnotata adults from different geographic locations was compared with $t$-tests adjusted by a post priori Bonferroni correction (critical $p=0.05 /$ number of comparisons; Scheiner and Gurevitch, 2001). Since all locations were not significantly different they were grouped. Adult beetle sizes across the two species ( $C$. septempunctata, $C$. novemnotata) and three origins (field collected, laboratory-reared, and museum collections) were analyzed using an ANOVA using JMP with experimental error 
rates controlled by using Tukey's Honest Significance Test for means separation tests. The relationship between the number of aphids offered per day and adult beetle size was also analyzed with a regression analysis on JMP with treatment levels log transformed to preserve linearity. The relationship between prey level and the proportion of individuals that survive to adulthood was analyzed as a logistic regression between the number of aphids offered per day and the number in each of two binomial states; survival (to adulthood) or death. Because of the parabolic shape of the relationship and because initial regression confirmed the significance of a quadratic term the number of aphids offered was transformed as $X-0.024 X^{2}$ prior to the analysis. $R^{2}$ for the transformed regression was estimated using Efron's $R^{2}$ which is equivalent to squaring the correlation coefficient between predicted and observed $Y$ values (Osborne, 2008).

\section{Results}

\subsection{Determining the most appropriate historical comparison}

Using a backward selection model-building process we determined the optimal model contained elevation, latitude, longitude and an elevation by latitude interaction. The equation for the optimal model was: Size $=26.24+0.002$ (Elevation) +0.25 (Latitude $)+0.08$ (Longitude $)+0.0003$ (Elevation $\times$ Latitude). Although a significant relationship was found for this model $(p=0.0001)$ it explains very little of the variation in beetle size $\left(R^{2}=0.10\right)$. Surprisingly, the relationship between all three factors (elevation, latitude, and longitude) and size was positive. This predicts that beetles will be larger as collection sites move towards higher elevations and in a northwesterly direction. Given that this positive relationship would predict larger rather than smaller beetles for our relatively high elevation samples from the northwestern US and given the low proportion of size variation explained we decided not to include any of the clines or their interactions in further analyses. We deemed it most appropriate to use a pooled mean measurement for all historical C. novemnotata specimens as the comparison against our recent samples.

\subsection{Size comparisons}

Factorial analysis of coccinellid species and origin revealed a significant effect of species $(p<0.0001)$ and origin $(p<0.0001)$ and a significant interaction between species and origin $(p=0.03)$. Across all origins, $C$. septempunctata adults were significantly larger than $C$. novemnotata adults with mean sizes of 38.17 and $29.29 \mathrm{~mm}^{2}$, respectively. Within each individual origin C. septempunctata adults were significantly larger than $C$. novemnotata adults. Across both species the size of recently field-collected adults (P1) were significantly smaller than the size of adults from historical collections that were significantly smaller than laboratory-reared adults (F1) with means of 30.75, 33.82, and $36.62 \mathrm{~mm}^{2}$, respectively. Since the interaction between species and origin was significant we compared individual species-origin combinations and found that this effect was driven primarily by C. novemnotata. Combined historical (collection) specimens were significantly larger than the recently collected $C$. novemnotata adults (P1) (Fig. 1). The offspring of the field-collected C. novemnotata adults reared in the laboratory without prey limitation (F1) were also significantly larger than their parental generation (Fig. 1). C. septempunctata adults collected from the field were not significantly different from either adults from historical collections or adults reared in the laboratory without prey limitation (Fig. 1).

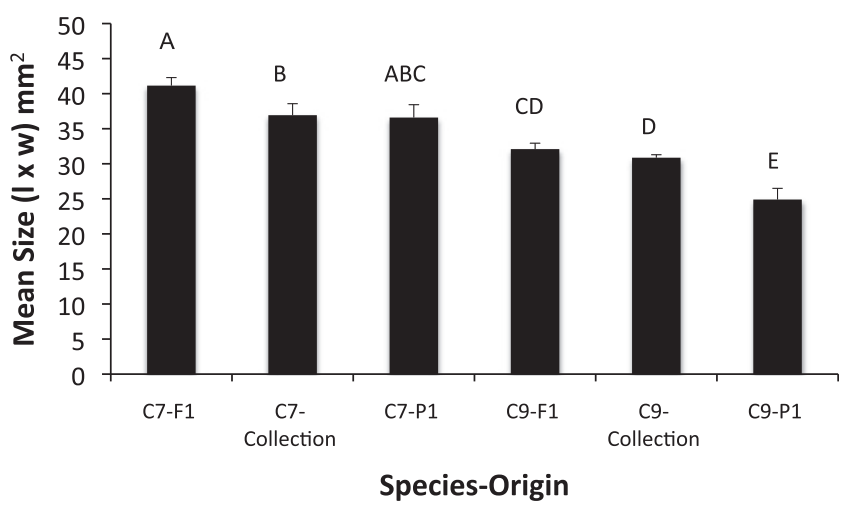

Fig. 1. Mean size ( $\mathrm{mm}^{2}$ with SEM as positive error bars) of $C$. novemnotata and $C$. septempunctata adults from recent field collections (P1), laboratory colonies (F1), and historical collections.

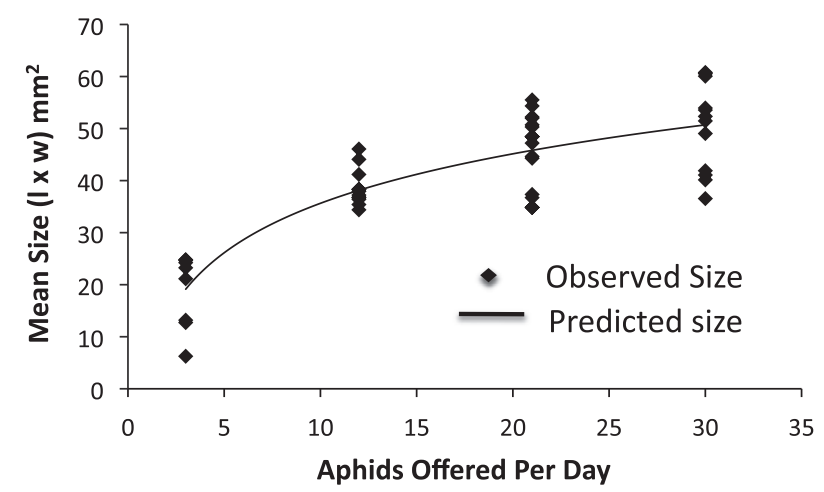

Fig. 2. Relationship between the number of aphids available per day to developing C. novemnotata larvae and resulting mean adult size $\left(\mathrm{mm}^{2}\right)$.

\subsection{Feeding study}

Prey availability during development was found to have a significant impact on adult $C$. novemnotata size and mortality. Prey availability had a significant positive relationship with adult beetle size $(p=0.0001)$ explaining over $70 \%$ of the variability $\left(R^{2}=0.72\right.$; see Fig. 2). Adult size (measured as $1 \times w$ ) ranged from $18.78 \mathrm{~mm}^{2}$ at a prey level of 3 per day to $50.12 \mathrm{~mm}^{2}$ at a prey level of 30 aphids per day. Prey availability also had a significant positive relationship with the proportion of larvae that survived to adulthood $(p<0.00001)$ explaining over $80 \%$ of the variability $\left(R^{2}=0.81\right.$; see Fig. 3$)$. The proportion of larvae that survived ranged from 0.00 when given one aphid per day to 0.75 at 21 aphids per day. Although the size of $C$. novemnotata individuals increased as prey availability increased from 21 to 30 aphids per day, the proportion of larvae that survived decreased to 0.60 at 30 aphids per day.

\subsection{Extrapolating feeding study data to field populations}

Based on a mean size of 24.90 for the recently field-collected adults this implies they may have had a diet of 4.57 aphids per day (95\% confidence limits 3.39-5.70) in the field. Based on our logistic relationship this implies a survival rate of approximately $23 \%$, which is less than a third of the mean maximum survival we found (75\%) at 21 aphids per day. 


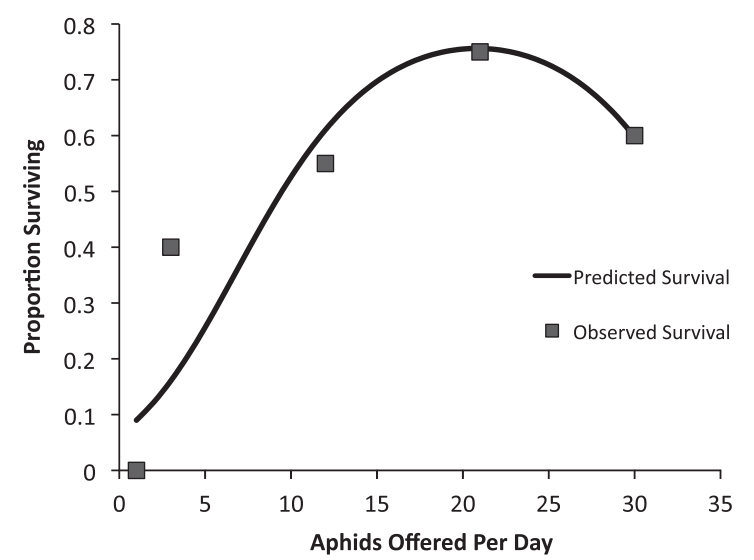

Fig. 3. Relationship between the number of aphids available per day to developing C. novemnotata larvae and resulting mean probability of survival to adulthood.

\section{Discussion}

When $C$. novemnotata adults were collected in the field, observations suggested that the mean size of these individuals was smaller than the mean historical size for this species. To test this hypothesis we first needed to determine if the adults we collected might be on the tail of an environmental cline. Pinned collections from around North America offered a wealth of data on historical size but it would have been inappropriate to compare the size of our adult beetles collected in the Northwest quadrant of the U.S. at relatively high altitudes to a simple mean size found in collections if the size of historical populations varied across either geographic location or altitude. Our results show that the size of adult $C$. novemnotata from historical populations did vary significantly across latitudinal, longitudinal, and elevational gradients. However, only a relatively small proportion of the variation was explained. It is interesting that size was positively correlated with elevation and latitude. This trend follows "Bergmann's rule" which was developed for warm-blooded vertebrates (Bergmann, 1847) and states that body size increases with latitude and more generally lower temperatures. The trend we found is counter to the trend that other studies have found for other insects (Vamosi et al., 2007; Peck and Chapelle, 2003; Orr, 1996). Since the analysis from pinned specimen data predicts that adult $C$. novemnotata from high elevations in the Northwestern U.S. should be relatively larger then those from other areas and since very little of the size variation is actually explained, we concluded that the most appropriate comparison of sizes of our recently collected adults (which we suspected were smaller) was with a large, broad mean of historical $C$. novemnotata adult sizes.

The recently collected $C$. novemnotata adults were significantly smaller than adults from historical populations (see Fig. 1). This raises two possibilities. Either $C$. novemnotata sizes have evolved to be smaller or the potential for larger sizes remains but adult beetles are prevented from attaining larger adult sizes because of ecological conditions (resource limitation, infection, size-dependent predation). When reared in the laboratory the first generation descendents (F1) of the field-collected adults (P1) were physically larger than (although not quite significantly) historical populations. This implies that the potential for larger adult size is genetically maintained in $C$. novemnotata and that whatever factor that is preventing them from reaching this size in the field is not present in the laboratory.

Although several factors could contribute to smaller size in the field, we focus on one bottom-up factor: prey availability. We reason that although pathogens can directly lower adult size (Boots and Begon, 1994), if infection was the cause of the smaller size of our beetles in the field it would have had the same impact in the captive population.

Following this line of reasoning we focus on prey availability as a plausible cause for the smaller size of recently collected $C$. novemnotata adults. Predatory insects show a range of responses to varying levels of prey availability during development. Lower prey levels during development can lead to decreases in survival to adulthood and smaller adult size (Pereyra and Archangelsky, 2007). This is the pattern that we found in our study (see Figs. 2 and 3). In fact, the mean size of field-collected adults fell within the range produced by our feeding trials, implying that prey limitation alone could produce the sizes we observed.

In our study, prey availability during development affected the probability of survival to adulthood as well as the size of the adults that emerged. The probability of survival through development increased with increasing prey availability in the range of 1-21 aphids/day but then declined going from 21 to 30 . This implies that for this species it is possible to eat too many aphids and lose fitness. The mean size of $C$. novemnotata adults we collected in the field were nowhere near this "obesity" level. Their average size was almost $25 \mathrm{~mm}^{2}$, which suggests they may have had access to approximately 5 aphids per day. This is a level of prey that exhibited only one third of the maximum survival we measured and could possibly have impacts on fecundity as well. The decreased fitness implied by the difference between current and historical adult $C$. novemnotata sizes appears severe enough to account for their observed decline in density and range.

If prey limitation is a contributing mechanism for decline, then the ultimate reason for the limited level of prey available to C. novemnotata and $C$. septempunctata deserves examination as a potential cause. This foreign species inhabits a very similar niche to $C$. novemnotata and usually in much higher densities. The Lost Ladybug Project lists 1758 records of $C$. septempunctata and only 45 for C. novemnotata. At the eastern Oregon collection site the ratio of $C$. septempunctata to $C$. novemnotata was greater than 20 to 1 . In a recent submission from Idaho, students in Jerry Severe's science class submitted over 730 identifiable lady beetle images to the Lost Ladybug Project. Over $75 \%$ of these were C. septempunctata while only 1 was a $C$. novemnotata. Beyond the disparity in density, $C$. septempunctata appears to be thriving at much closer to its potential than $C$. novemnotata based on the lack of difference between the size of field-collected, historical and laboratory-reared individuals (see Fig. 1). One insect predator may limit the prey available to another by interference with foraging (McPeek et al., 2001) or more commonly through scramble competition. There are documented cases of native predator species suffering lowered access to prey through scramble competition with the introduced species (Elliot et al., 1996; Evans, 1991).

If scramble competition is lowering prey densities available to C. novemnotata during development the immediate result could be smaller adult size. Day and Tatman (2006) suggest that northeastern aphid populations are, in fact, steadily declining. Evans (2000) did not find evidence for a decline in body size for five native species as $C$. septempunctata densities increased in Utah in the 1990s. C. novemnotata, which was already very rare in Utah at that time, was not found in sufficient number to be included in the analysis (Evans, 2000). The evidence that (1) both species occur in the same habitats, (2) they are known to exploit the same prey, and (3) that lack of prey could cause the decline in mean C. novemnotata body size observed, inspired the hypothesis that C. novemnotata sizes have diminished due to lack of prey caused by scramble competition with $C$. septempunctata and that the smaller size of $C$. novemnotata is associated with lower fitness that led to their decline. 
Some authors have suggested that $C$. septempunctata cannot be the sole reason for the decline of $C$. novemnotata because in some areas the decline seems to have preceded the invasion (Fothergill and Tindall, 2010). C. septempunctata may have moved in to occupy an incompletely filled niche after $C$. novemnotata had already begun its decline. In this case the main role of $C$. septempunctata may have been in preventing the reestablishment or rebounding of $C$. novemnotata. However, it also seems possible that upon arrival in new areas the earliest $C$. septempunctata invaders were misidentified or simply missed while still at low densities. Delayed detection has been documented for other invasive insects such as the cereal leaf beetle, Oulema melanopus (Haynes and Gage, 1981). While the introduced species is unlikely to have had a major impact at low initial densities its being overlooked could have caused the invasion clock to be initiated with an incorrect date. It also seems plausible a "wave of decline" could have hit a native species like $C$. novemnotata in a given area before the invading species arrived. If $C$. novemnotata dispersed equally in all directions but back dispersal was limited from one or more directions due to previous decline in another region, then decline could have preceded invasion. These types of sinks for populations, termed ecological traps, have been examined theoretically (Robertson and Hutto, 2006) and their potential to impact insect predator populations has been documented (Ries and Fagan, 2003).

Our study demonstrates that $C$. novemnotata adults are significantly smaller than they were historically and that prey availability alone is sufficient to account for this decrease in size. While our evidence is consistent with expectations if $C$. septempunctata were to negatively impact $C$. novemnotata through scramble competition, it is not exclusive of other potential mechanisms including competition for non-prey resources, intraguild predation, introduction of parasitoids or pathogens, and hybridization (Harmon et al., 2007). We suggest further study of current and historical distributions of $C$. novemnotata and $C$. septempunctata along with directed laboratory studies and modeling efforts to elucidate if $C$. septempunctata played a role in prey limitation leading to the decline of $C$. novemnotata.

\section{Acknowledgments}

The authors would like to thank Leonard Stellwag and Eric Beckendorf for their management of the laboratory coccinellid colonies at Cornell and Brookings, respectively.

\section{References}

Alyokhin, A., Sewell, G., 2004. Changes in a lady beetle community following the establishment of three alien species. Biological Invasions 6, 463-471.

Bergmann, C., 1847. Ueber die Verhaeltnisse der Waermeoekonomie der Thiere zu ihrer Groesse. Goettinger Studien (Pt. 1), 595-708.

Blackman, R.L., 1965. Studies on specificity in Coccinellidae. Annals of Applied Biology 56, 336-338.

Blueweiss, L., Fox, H., Kudzma, V., Nakashima, D., Peters, R., Sams, S., 1978 Relationships between body size and some life history parameters. Oecologia 37, 257-272.

Boots, M., Begon, M., 1994. Resource limitation and the lethal and sublethal effects of a viral pathogen in the Indian meal moth, Plodia interpunctella. Ecological Entomology 19, 319-326.

Brown, J.H., Maurer, B.A., 1986. Body size, ecological dominance and Cope's rule. Nature 324, 248-250.

Day, W.H., Tatman, K.M., 2006. Changes in abundance of native and adventive Coccinellidae (Coleoptera) in alfalfa fields in northern New Jersey (1993-2004) and Delaware (1999-2004), USA. Entomological News 117, 491.

Dingle, H., 1984. Behavior, genes, and life histories: complex adaptations in uncertain environments. In: Price, P.W., Slobodchikoff, C.N., Gaud, W.S. (Eds.), A New Ecology: Novel Approaches to Interactive Systems. John Wiley \& Sons, Inc., New York, pp. 169-194.

Elliot, N.C., Kieckhefer, R., Kauffman, W., 1996. Effects of an invading coccinellid on native coccinellids in an agricultural landscape. Oecologia 105, 537-544.
Ellis, D.R., Prokrym, D.R., Adams, R.G., 1999. Exotic lady beetle survey in northeastern United States: Hippodamia variegata and Propylea quaturodecimpunctata (Coleoptera: Coccinellidae). Entomol. News. 110, 73-84. Evans, E.W., 1991. Intra and interspecific interactions of lady beetles (Coleoptera: Coccinellidae) attacking aphids. Oecologia 87, 401-408.

Evans, E.W., 2000. Morphology of invasion: body size patterns associated with establishment of Coccinella septempunctata (Coleoptera: Coccinellidae) in western North America. European Journal of Entomology 97, 469-474.

Fothergill, K., Tindall, K.V., 2010. Lady beetle (Coleoptera: Coccinellidae: Coccinellinae) occurrences in Southeastern Missouri agricultural systems: differences between 1966 and present. The Coleopterists Bulletin 64, 379-382.

Gordon, R.D., 1985. The Coccinellidae (Coleoptera) of America North of Mexico. Journal of the New York Entomological Society 93, 1-912.

Gullan, P.J., Cranston, P.S., 1994. The Insects. An Outline of Entomology. Chapman \& Hall, New York.

Harmon, J., Stephens, E.J., Losey, J.E., 2007. The decline of native coccinellids (Coleoptera: Coccinellidae) in the United States and Canada. Journal of Insect Conservation $11,85-94$.

Haynes, D.L., Gage, S.H., 1981. The cereal leaf beetle in North America. Annual Review of Entomology 26, 259-287.

Hodek, I., Honek, A., 1996. Ecology of Coccinellidae. Kluwer Academic Publishers, Dordrecht, The Netherlands.

Hoffmann, M.P., Frodsham, A.C., 1993. Natural Enemies of Vegetable Insect Pests. Cooperative Extension, Cornell University, Ithaca, NY.

Honek, A., 1993. Intraspecific variation in body size and fecundity in insects: a general relationship. Oikos 66, 483-492.

Howard, R.D., Moorman, R.S., Whiteman, H.H., 1997. Differential effects of mate choice and mate competition on eastern tiger salamanders. Animal Behaviour 53, 1345-1356.

Losey, J.E., Perlman, J.E., Hoebeke, R., 2007. Citizen scientist rediscovers rare ninespotted lady beetle, Coccinella novemnotata, in eastern North America. Journal of Insect Conservation 11, 415-417.

Menge, B.A., 1972. Competition for food between two intertidal starfish species and its effect on body size and feeding. Ecology 53, 635-644.

McPeek, M.A., Grace, M., Richardson, J.M.L., 2001. Physiological and behavioral responses to predators shape the growth/predation risk trade-off in damselflies. Ecology 82, 1535-1545.

Naguib, M., Gil, D., 2005. Transgenerational body size effects caused by early developmental stress in zebra finches. Biology Letters 1, 95-97.

Obrycki, J.J., Orr, C.J., 1990. Suitability of three prey species for Nearctic populations of Coccinella septempunctata, Hippodamia variegata, and Propylea quatuordecimpunctata (Coleoptera: Coccinellidae). Journal of Economic Entomology 83, 1292-1297.

Orr, C.J., Obrycki, J.J., 1990. Thermal and dietary requirements for development of Hippodamia parenthesis (Coleoptera: Coccinellidae). Environmental Entomology 19, 1523-1527.

Orr, M.R., 1996. Life-history adaptation and reproductive isolation in a grasshopper hybrid zone. Evolution 50, 704-716.

Osborne, J., 2008. Best Practices in Quantitative Methods. Sage, London.

Peck, L.S., Chapelle, G., 2003. Reduced oxygen at high altitude limits maximum size. Proceedings of the Royal Society of London. Series B: Biological Sciences 270, $166-167$.

Pereyra, D., Archangelsky, M., 2007. The effect of prey density on the developmental time of larvae of an aquatic beetle: Tropisternus setiger (Insecta, Coleoptera: Hydrophilidae). Hydrobiologia 586, 367-372.

Phillips, B.L., Shine, R., 2004. Adapting to an invasive species: toxic cane toads induce morphological change in Australian snakes. Proceedings of the National Academy of Sciences of the United States of America 101, 17150-17155.

Phoofolo, M.W., Giles, K.L., Elliott, N.C., 2008. Larval life history responses to food deprivation in three species of predatory lady beetles (Coleoptera: Coccinellidae). Environmental Entomology 37, 315-322.

Ries, L., Fagan, W., 2003. Habitat edges as a potential ecological trap for an insect predator. Ecological Entomology 28, 567-572.

Robertson, B.A., Hutto, R.L., 2006. A framework for understanding ecological traps and an evaluation of existing evidence. Ecology 87, 1075-1085.

Roy, K., 2008. Dynamics of body size evolution. Science 321, 1451.

Savage, V.M., Gilooly, J.F., Brown, J.H., West, G.B., Charnov, E.L., 2004. Effect of body size and temperature on population growth. American Naturalist 163, 429-441.

Scheiner, S.M., Gurevitch, J., 2001. Design and Analysis of Ecological Experiments. Oxford University Press, London.

Simberloff, D., Stiling, P., 1996. How risky is biological control? Ecology 77, 19651974.

Smith, F.A., Betancourt, J.L., Brown, J.H., 1995. Evolution of body size in the woodrat over the past 25,000 years of climate change. Science $270,5244-5246$.

Snyder, W.E., Clevenger, G.M., Eigenbrode, S.D., 2004. Intraguild predation and successful invasion by introduced ladybird beetles. Oecologia 140, 559-565.

Staines Jr., C.L., Rothschild, M.J., Trumble, R.B., 1990. A survey of the Coccinellidae associated with nursery stock in Maryland. Proceedings of the Entomological Society of Washington 92, 310-313.

Vamosi, S.M., Naydani, C.J., Vamosi, J.C., 2007. Body size and species richness along geographical gradients in Albertan diving beetle (Coleoptera: Dytiscidae) communities. Canadian Journal of Zoology 85, 443-449.

Wheeler, A.G., Hoebeke, E.R., 1995. Coccinella novemnotata in Northeastern North America: historical occurrence and current status (Coleoptera: Coccinellidae). Proceedings of the Entomological Society of Washington 97, 701-716. 